\title{
Tribology and Dowson
}

\author{
Nicholas John Morris ${ }^{1}$ (D) Patricia M. Johns-Rahnejat ${ }^{2, *}$ and Homer Rahnejat ${ }^{2}$ ad \\ 1 Wolfson School of Mechanical, Electrical and Manufacturing Engineering, Loughborough University, \\ Loughborough, Leicestershire LE11 3TU, UK; N.J.Morris@lboro.ac.uk \\ 2 The School of Engineering, University of Central Lancashire, Preston, Lancashire PR1 2HE, UK; \\ enhr54@gmail.com \\ * Correspondence: PJohns-Rahnejat@uclan.ac.uk
}

Received: 3 June 2020; Accepted: 4 June 2020; Published: 9 June 2020

check for updates

\section{Introduction}

It is with great sadness that we note the passing of Professor Duncan Dowson on 6th January 2020. Duncan was an esteemed member of the Editorial Board of this journal.

He will be remembered as one of the founding fathers of tribology and as a true gentleman. He was the last living member of the Jost Committee, set up by the UK Government (1964-1966) to investigate the state of lubrication education and research, and to establish the requirements of industry in this regard [1]. This committee coined the term "tribology".

Duncan contributed to many areas of tribological research and established many of them, including elastohydrodynamic theory and biotribology.

His research interests have provided both academic and practising industrial tribologists with many analytical tools and methods, including the Dowson and Higginson extrapolated oil film thickness formula for the prediction of minimum film thickness in lubricated line contacts, and the Hamrock and Dowson oil film thickness formula for lubricated point contacts. He also provided a formula for film thickness for hip joint prostheses, which emanated from his innovative research on the design of pioneering total hip arthroplasty in the 1960s.

The publication of more than 600 papers and five books is testament to Duncan's vast contribution to science and engineering. In addition, he has also been the Editor of several engineering journals, including Wear and the Proceedings of the Institution of Mechanical Engineers, Part C: Journal of Mechanical Engineering Science and Part H: Journal of Engineering in Medicine. He played a key role in creating a global tribological research community, organising many events, including the long-running (since 1974) Leeds-Lyon Symposium on Tribology, which he co-founded with the late Professor Maurice Godet of Institut National des Sciences Appliquées (INSA) Lyon.

Duncan was one of the most decorated scientists of our times, over a career that spanned seven decades. His distinctions include Fellow of the Royal Society (FRS), Commander of the Most Excellent Order of the British Empire (CBE), Honorary Fellow of the Royal Society of Edinburgh (FRSE) and Fellow of the Royal Academy of Engineering (FREng). His accolades include seven honorary doctorates from both national and international universities, and numerous scientific and technical awards, including the Thomas Hawksley Gold Medal, the British Society of Rheology Gold Medal, the Tribology Gold Medal, the James Alfred Ewing Medal, the Kelvin Medal and the James Watt International Gold Medal.

This journal recognised his immense long-standing achievements in 2018, by establishing the annual Duncan Dowson Travel Grant, which is subject to competition by young $\mathrm{PhD}$ and Post-doctoral researchers intending to present at a tribology-related conference.

Lubricants is honoured to publish this special issue dedicated to the memory of Duncan Dowson, edited by guest editors Nicholas Morris and Patricia Johns-Rahnejat, who enjoyed his advice and guidance. 
We are very grateful for all the contributions submitted in so many aspects of tribology in commemoration of the achievements of Duncan Dowson.

\section{Contributions of Duncan Dowson}

As already noted, Duncan Dowson contributed immensely to the field of tribology. In particular, he made innovative contributions to hydrodynamics and elastohydrodynamics and the application of these to bearings, engine and powertrain tribology as well as to biotribology. He is regarded as the father of biotribology and a pioneer in the establishment of elastohydrodynamic theory. He also contributed significantly to other areas, such as nanotribology and contact mechanics. His research remained at the leading edge of developments right up to his unfortunate death in January 2020.

Duncan enjoyed a remarkable research career spanning nearly 70 years, with hundreds of published papers and important books. Therefore, it is well beyond the scope of this editorial to recount all his many contributions. Instead, we will confine ourselves to highlighting the significance of his work by placing some of his seminal contributions within the context of research developments in tribology at the time.

\subsection{Elastohydrodynamic Lubrication (EHL)}

The ground-breaking contribution to the field of lubrication was made by Osborne Reynolds [2] who developed the theory for hydrodynamics in narrow conjunctions of lubricated contacts. He demonstrated that a converging wedge-shaped film of fluid generated high contact pressures. Therefore, the presence of a rising and falling pressure distribution along a hydrodynamic wedge endows it with a load carrying capacity. Reynolds concluded that the load carrying capacity is the raison d'être of all hydrodynamic bearings. If the applied load were to exceed the hydrodynamic load capacity of a bearing, there should be some evidence of wear. Therefore, the absence of wear under such prescribed conditions (where the applied load exceeded the predicted hydrodynamic load capacity) was rather puzzling at that time. For instance, Martin [3] used Reynolds' equation to predict the hydrodynamic lubricant film thickness between meshing spur gear teeth pairs when they were represented by a pair of rigid cylinders, and remarked on the absence of wear, which should have been present with his very thin predicted films.

The problem with the early applications of Reynolds' hydrodynamic theory to gears and rolling element bearings at medium to relatively high loads was twofold. Firstly, the hydrodynamic theory assumed iso-viscous fluid behaviour (no changes in lubricant viscosity with pressure). Secondly, contacting bodies are not rigid and, due to the concentrated nature of their contact, can undergo localised deformation, thus increasing the conjunctional gap between them when subjected to sufficient load. The problem of localised deflection of contacting solids of revolution under small strain was tackled by Heinrich Hertz [4] around the same time as the advancements of Osborne Reynolds. However, there is no evidence that the two scientists ever communicated. Consequently, the clear connection between Reynolds' hydrodynamics and Hertzian contact mechanics took a further half-century to emerge.

In the period 1936-1941, various researchers investigated the effect of elastic deformation of loaded rolling contacting members on the potential formation of a lubricant film in their contact $[5,6]$. These analyses were based on Hertzian contact mechanics under dry contact conditions. Such studies gave credence to the supposition that led to Ertel and Grubin's [7] piezo-viscous-elastic hypothesis and the definition of elastohydrodynamic lubrication. Petrusevitch [8] confirmed the findings of Ertel and Grubin [7], proposing an initial solution that satisfied both hydrodynamic and elasticity equations, but not in an integrated manner. A numerical solution of elastohydrodynamic lubrication for the assumed case of infinite line contact of rollers was presented by Dowson and Higginson [9]. This solution is regarded as the first detailed and accurate representation of EHL. Dowson and Higginson [10] also provided early supplementary contributions, undertaking parametric sensitivity analysis for EHL line contact. This led to their seminal and long-lasting book "Elasto-Hydrodynamic 
Lubrication" [11], as well as the Dowson and Higginson lubricant film thickness formula for EHL line contact [12]. By 1962, Dowson [13] had proposed the generalised form of Reynolds' equation for the solution of hydrodynamic problems, including for bearings and seals. This approach was extended to the case of EHL analysis.

The finite difference solution for the case of the circular point contact of a ball on a flat race was presented by Cameron and Gohar [14] in 1966. In fact, Duncan Dowson and his contemporary Ramsey Gohar, whilst rarely co-authors, consulted regularly throughout their working lives, and were two of the most influential researchers in the early developments of EHL theory and experimentation, including interferometry $[15,16]$. They both developed theory for EHL of point contacts, with Dowson providing a series of papers dealing with finite difference solutions of circular and elliptical point contacts under different conditions, including for fully flooded and starved inlet boundaries [17-20], in addition to providing some new oil film thickness equations for different regimes of lubrication. Later, it was noted that the lubricant film thickness would alter in various applications, owing to changes in contact kinematics or transient effects, such as squeeze film motion. Variations in the direction of lubricant entrainment were analysed by Dowson, as well as by a number of his contemporaries, with some providing new and more comprehensive equations [21-26]. Other solutions have included the effect of squeeze film motion or surface waviness under transient conditions where, owing to squeeze film effect, the load carrying capacity of the contact is enhanced [27-33]. Dowson contributed to many of the other developments of EHL theory, applications and/or methods of solution. One important issue has been thermal effects; others are non-Newtonian shear and micro-elastohydrodynamics (EHL of rough surfaces) [34-37]. As early as 1979, the 6th Leeds-Lyon Symposium [38,39] was dedicated to the generated heat in hydrodynamic/elastohydrodynamic conjunctions.

The mechanics of contact is critical to the durability of load bearing surfaces, with the limiting factor often being the generated sub-surface stresses, which can lead to fatigue spalling and the exfoliation of coatings and overlays. Therefore, the determination of such stresses is an important consideration, as noted by Dowson and Higginson [10]. The sub-surface stresses are induced by applied contact pressures and surface traction in load transmitting conjunctions [40]. This area of research was closely followed by another of Duncan Dowson's contemporaries, Kenneth Johnson, who studied rolling contact fatigue under various conditions [41,42], as well as surface adhesion [43]. The determination of sub-surface stresses is critical in the assessment of fatigue life of contacts [44], often requiring detailed numerical analysis [45-47]. In many cases, these stresses depend on surface coatings that are often used for a multitude of reasons such as wear-resistance, reduced friction, etc. Dowson was an early contributor to this area of research [10,48], advancing predictive methods for soft overlays in hip and knee joint prostheses [49,50] and for coatings in bearings and gears [51].

\subsection{Engine and Powertrain}

Throughout his career, Duncan Dowson developed many applications of hydrodynamic and elastohydrodynamic theories. His main interest and most of his contributions were in the tribology of biological systems, particularly in the endo-articular joints; the hip and knee (Section 2.3). However, he also contributed significantly to applications of EHL and hydrodynamic theories for the prediction of tribological conditions in internal combustion (IC) engines and other powertrain subsystems (such as gearing systems $[11,52,53]$ ), with the aim of improving their energy efficiency $[54,55]$. With regard to IC engines, Dowson conducted research in all the major tribological conjunctions, including cam-follower pairs, which are subject to EHL [56,57]. His experimental monitoring of lubricant film thickness using its electrical resistivity [57] had only previously been measured by Hamilton [58], using a deposited capacitive micro-transducer. Hamilton first reported the use of these transducers for the piston ring conjunction [59]. Capacitive, pressure and temperature sensitive micro-transducers have been used to monitor contact conditions in a variety of applications, including some under EHL conditions [60-65]. 
Dowson also paid considerable attention to piston-cylinder conjunctions as piston rings and piston skirt conjunctions account for nearly $50 \%$ of all the frictional losses of an IC engine, which, in turn, accounts for $15-25 \%$ of all the engine losses. Other sources of loss are thermal and pumping losses. Dowson's initial work on piston rings [66] set the scene for analytical EHL predictive research in this area, which includes multi-physics integrated lubrication, dynamics and gas flow analyses. He also worked on the cavitation boundary and contact exit boundary condition [67], as well as on the effect of cylinder liner temperature on the lubrication and friction of piston compression ring conjunctions [68]. His research on piston-cylinder systems includes the effect of surface coatings of liners, and the topical issue of surface modification/texturing of liners and piston skirts with engine testing, to ascertain their impact on friction [69]. Improved lubricant film thickness was found both experimentally and through numerical predictions in the case of surface texturing, owing to its micro-hydrodynamic effect [70]. This was an area of special interest to Dowson, as micro-elastohydrodynamics is inherent to the behaviour of rough cartilage in the lubrication of natural joints (Section 2.3).

Dowson was also keen to investigate the effect of new engine technologies upon frictional performance. In particular, the effect of cylinder deactivation (CDA) technology was investigated, showing that tribology should be taken into account in the design of modern engines using new technologies, such as CDA [71,72].

\subsection{Biotribology}

The unification of the study of friction, wear and lubrication into the integrated discipline of tribology was a step-change for engineering [1]. It is notable that the Jost report [1], which surveyed practitioners of the newly defined discipline, did not mention those concerned with biological systems. At the time, synovial joint arthroplasty was the domain of highly skilled medical practitioners, such as Charnley (Wrightington Hospital), McKee (Norfolk and Norwich Hospital), Scales and Wilson (Stanmore), Ring (Redhill) and Ling and Lee (Exeter). The extension of tribological research into the biological domain flourished with the introduction of John Charnley to Duncan Dowson. The rapid technological advances of the 1960s and 1970s in total joint replacement is the result of the collaboration between mechanical engineers and medical researchers, amongst which Dowson was a true pioneer.

By the middle of the 20th century, there were several explanations for the mechanism of mammalian synovial joint lubrication. Charnley [73], at the newly inaugurated Hip Centre at Wrightington Hospital, suggested that synovial joints relied on boundary phenomena. MacConaill [74] proposed a hydrodynamic mechanism, whilst McCutchen [75] suggested a weeping mechanism of lubrication. Clarity was provided at a landmark symposium held in 1967, organised by Dowson and Neale on behalf of the Institution of Mechanical Engineers (IMechE), with Charnley and Scales representing the British Orthopaedic Association (BOA). At this event, Dowson used a mechanical bearing analogy to demonstrate that the primary modes of lubrication were elastohydrodynamic and squeeze film effect in origin [76]. He also noted that complementary mechanisms related to boundary lubrication would be of significant importance [76]. Shortly afterwards, Dowson, who was at this point the Chairman of the IMechE Tribology group, coined the term biotribology [77] and provided evidence of the complementary mechanisms of entrapment and enrichment [77-79].

Prior to the mechanistic understanding of tribology of synovial joints, remarkable progress was already being made in the United Kingdom on the development of experimental total joint arthroplasty. Operations were conducted by surgeons in an attempt to alleviate severe and chronic joint conditions. The first recorded of these operations was conducted by Wiles in 1938 using stainless steel components [80]. The Mckee-Farrar joint was developed in the 1950s, and widely adopted for patients in 1961. It used a more inert chromium-cobalt alloy steel with much greater success [81,82]. The McKee-Farrar joint was designed to prioritise minimal wear, whilst Charnley placed a greater emphasis on the minimisation of friction, pioneering a metallic femoral head paired with a polymeric acetabular cup. At first, polytetrafluoroethylene (PTFE) polymer was used for the acetabular socket. This caused a number of unwanted issues for the recipients. The search for an alternative polymer led 
to the meeting of Dowson and Charnley when the latter took an interest in Dowson's development of novel bearing materials for use in the presence of water and environments of high humidity for the Ministry of Defence, leading to the use of ultra-high molecular weight polyethylene (UHMWPE) [83]. This began a lasting relationship between the two men, and many visits to Leeds and Wrightington ensued [84]. The Charnley low-friction arthroplasty [82] (generally referred to as the "Charnley joint") with $22.225 \mathrm{~mm}$ diameter metal femoral head and thick UHMWPE socket was the first total hip replacement to be adopted worldwide. When Dowson invited his colleague Longfield to conduct an analysis of the Charnley joint, it was found that the manufactured dimension was actually very close to optimal (25-27 mm) when considering wear [84-86]. To date, the Charnley joint with significant contributions by Dowson remains the gold standard for total hip replacement.

Innovative numerical solutions for elastohydrodynamic lubrication problems pioneered by Dowson provided further insights into the mechanism of ankle, knee and hip synovial joint lubrication. He showed the action of articular cartilage rugosity using numerical micro-elastrohydrodynamic perturbations [87] and, from similar numerical analysis, derived empirical formulae for film thickness and load carrying capacity of the major synovial joints [88]. Dowson investigated total joint replacement with an UHMWPE acetabular component, cushion bearing behaviour for knee and hip arthroplasty [89,90] and lubrication of total hip replacement joints created with materials of high elastic modulus [91]. Alongside his numerical research, he had a successful programme of experimental research, focusing on the wear of total hip joint replacement [92-95] and knee joint replacement [96-100].

Dowson presented his definitive review, entitled: "New joints for the Millennium" at the IMechE in 2000 [101]. He continued to contribute to the advancement of understanding in total joint replacement in many areas, such as joint simulator performance of metal-on-metal joints [102], tribo-corrosion and tribo-film formation on medical implants [103-105], non-Newtonian effects in metal-on-metal joints [106], wear modelling of metal-on-metal joints [102,107], poro-elastic effects of endo-articular cartilage [50] and hydrogels [108].

\section{Closure}

The foregoing is a short commemoration of Duncan Dowson's achievements and contributions to all aspects of tribology. It is but a very brief recounting of his work, covering nearly seven decades of his most pertinent, pioneering and original contributions. In addition, he worked widely with many other researchers, who benefited from his patient and considered guidance.

Duncan was a forerunner in the development of elastohydrodynamic theory and the leading light in biotribology. The community of tribologists and all those practising any aspect of the broad subject will benefit directly for many years to come from his sustained and long-standing contributions. In particular, total hip replacement, now one of the most common elective surgeries, is thought of as one of the landmark surgeries of the 20th century. Indeed, the majority reading this article will have benefited, either personally or through a loved one, from such an operation. For more than sixty years, Duncan Dowson sustained invaluable contributions towards the advancement of total joint replacement prostheses. For this, and so much more, he is owed an immense debt of gratitude.

\section{References}

1. Jost, P. The Introduction of New Technology: Report of the Committee on Tribology; Her Majesty's Stationary Office: London, UK, 1966.

2. Reynolds, O. On the theory of lubrication and its application to Mr. Beauchamp tower's experiments, including an experimental determination of the viscosity of olive oil. Phil. Trans. R. Soc. Lond. 1886, 177, 157-234.

3. Martin, H.M. Lubrication of gear teeth. Eng. Lond. 1916, 102, 119.

4. Hertz, H. Uber die Berührung fester elastischer Körper. J. Für Die Reine Und Angew. Math. 1882, 92, $156-171$.

5. Peppler, W. Untersuchungen Uber Die Druckubertragung Bei Belasteten Und Geschmierten Umlaufenden Achsparallelen Zylindern; Maschinenelemente-Tagung: Aachen, Germany, 1935. 
6. Meldahl, A. Contribution to the theory of the lubrication of gears and the stressing of the lubricated flanks of gear teeth. Brown Boveri Rev. 1941, 28, 374-382.

7. Grubin, A.N. Contact Stresses in Toothed Gears and Worm Gears, Book 30 CSRI for Technology and Mechanical Engineering; CSRI (Central Scientific Research Institute): Moscow, Russia, 1949.

8. Petrusevitch, A.I. Fundamental conclusions from the contact-Hydrodynamic theory of lubrication. Izv. Uzb. Fil. Akad. Nauk. 1951, 2, 209.

9. Dowson, D.; Higginson, G.R. A Numerical Solution to the Elasto-Hydrodynamic Problem. J. Mech. Eng. Sci. 1959, 1, 6-15. [CrossRef]

10. Dowson, D.; Higginson, G.R. The Effect of Material Properties on the Lubrication of Elastic Rollers. J. Mech. Eng. Sci. 1960, 2, 188-194. [CrossRef]

11. Dowson, D.; Higginson, G.R. Elasto-Hydrodynamic Lubrication; Pergamon Press: Oxford, UK, 1966.

12. Dowson, D.; Higginson, G.R. New roller bearing lubrication formula. Engineering 1961, 192, 158.

13. Dowson, D. A generalized Reynolds equation for fluid-film lubrication. Int. J. Mech. Sci. 1962, 4, 159-170. [CrossRef]

14. Cameron, A.; Gohar, R. Theoretical and experimental studies of the oil film in lubricated point contact. Proc. R. Soc. Lond. Ser. A Math. Phys. Sci. 1966, 291, 520-536.

15. Gohar, R.; Cameron, A. Optical Measurement of Oil Film Thickness under Elasto-hydrodynamic Lubrication. Nature 1963, 200, 458-459. [CrossRef]

16. Dowson, D.A.J.D.; Jones, D.A. Lubricant Entrapment between Approaching Elastic Solids. Nature 1967, 214, 947-948. [CrossRef]

17. Hamrock, B.J.; Dowson, D. Isothermal elastohydrodynamic lubrication of point contacts: Part 1-Theoretical formulation. J. Lubr. Tech. 1976, 98, 223-228. [CrossRef]

18. Hamrock, B.J.; Dowson, D. Isothermal Elastohydrodynamic Lubrication of Point Contacts: Part II—Ellipticity Parameter Results. J. Lubr. Technol. 1976, 98, 375-381. [CrossRef]

19. Hamrock, B.J.; Dowson, D. Isothermal Elastohydrodynamic Lubrication of Point Contacts: Part III—Fully Flooded Results. J. Lubr. Technol. 1977, 99, 264-275. [CrossRef]

20. Hamrock, B.J.; Dowson, D. Isothermal Elastohydrodynamic Lubrication of Point Contacts: Part IV-Starvation Results. J. Lubr. Technol. 1977, 99, 15-23. [CrossRef]

21. Thorp, N.; Gohar, R. Oil Film Thickness and Shape for a Ball Sliding in a Grooved Raceway. J. Lubr. Technol. 1972, 94, 199-208. [CrossRef]

22. Chittenden, R.J.; Dowson, D.; Dunn, J.F.; Taylor, C.M. A theoretical analysis of the isothermal elastohydrodynamic lubrication of concentrated contacts-I: Direction of lubricant entrainment coincident with the major axis of the Hertzian contact ellipse. Proc. R. Soc. 1985, 397, 245-269.

23. Chittenden, R.J.; Dowson, D.; Dunn, J.F.; Taylor, C.M. A Theoretical Analysis of the Isothermal Elastohydrodynamic Lubrication of Concentrated Contact-Part II: General Case, With Lubricant Entrainment Along Either Principal Axis of the Hertzian Contact Ellipse or at Some Intermediate Angle. Proc. R. Soc. 1985, 397, 271-294.

24. Mostofi, A.; Gohar, R. Oil Film Thickness and Pressure Distribution in Elastohydrodynamic Point Contacts. J. Mech. Eng. Sci. 1982, 24, 173-182. [CrossRef]

25. Jalali-Vahid, D.; Rahnejat, H.; Gohar, R.; Jin, Z.M. Comparison between experiments and numerical solutions for isothermal elastohydrodynamic point contacts. J. Phys. D Appl. Phys. 1998, 31, 2725-2732. [CrossRef]

26. Jalali-Vahid, D.; Gohar, R.; Rahnejat, H.; Jin, Z.M. Prediction of oil-film thickness and shape in elliptical point contacts under combined rolling and sliding motion. Proc. Inst. Mech. Eng. Part J J. Eng. Tribol. 2000, 214, 427-437. [CrossRef]

27. Rahnejat, H.; Gohar, R. The Vibrations of Radial Ball Bearings. Proc. Inst. Mech. Eng. Part C J. Mech. Eng. Sci. 1985, 199, 181-193. [CrossRef]

28. Bedewi, M.; Dowson, D.; Taylor, C.M. The squeeze-film lubrication of ellipsoids. J. Phys. D Appl. Phys. 1992, 25, A133-A140. [CrossRef]

29. Ehret, P.; Dowson, D.; Taylor, C.M. Transient EHL Solutions with Interfacial Slip. J. Tribol. 1999, 121, 703-710. [CrossRef]

30. Ehret, P.; Dowson, D.; Taylor, C. Time-Dependent Solutions with Waviness and Asperities in EHL Point Contacts. Tribol. Ser. 1997, 32, 313-324. [CrossRef] 
31. Vahid, D.J.; Rahnejat, H.; Jin, Z.M.; Downson, D. Transient analysis of isothermal elastohydrodynamic circular point contacts. Proc. Inst. Mech. Eng. Part C J. Mech. Eng. Sci. 2001, 215, 1159-1172. [CrossRef]

32. Venner, C.H.; Lubrecht, A. Transient Analysis of Surface Features in an EHL Line Contact in the Case of Sliding. J. Tribol. 1994, 116, 186-193. [CrossRef]

33. Kushwaha, M.; Rahnejat, H. Transient concentrated finite line roller-to-race contact under combined entraining, tilting and squeeze film motions. J. Phys. D Appl. Phys. 2004, 37, 2018-2034. [CrossRef]

34. Dowson, D. Elastohydrodynamic and micro-elastohydrodynamic lubrication. Wear 1995, 190, $125-138$. [CrossRef]

35. Venner, C.H.; Napel, W.E.T. Surface Roughness Effects in an EHL Line Contact. J. Tribol. 1992, 114, 616-622. [CrossRef]

36. Jin, Z.; Yang, P.; Cui, J.; Dowson, D. Transient elastohydrodynamic analysis of elliptical contacts. Part 1: Isothermal and Newtonian lubricant solution. Proc. Inst. Mech. Eng. Part J J. Eng. Tribol. 2004, 218, 211-224. [CrossRef]

37. Yang, P.; Cui, J.; Jin, Z.; Dowson, D. Transient elastohydrodynamic analysis of elliptical contacts. Part 2: Thermal and Newtonian lubricant solution. Proc. Inst. Mech. Eng. Part J J. Eng. Tribol. 2005, 219, 187-200. [CrossRef]

38. Dowson, D.; Taylor, C.M.; Godet, M.; Berthe, D. Thermal Effects in Tribology. In Proceedings of the 6th Leeds-Lyon Sympos, Lyon, France, 18-21 September 1979.

39. Pinkus, O.; Wilcock, D.J. Thermal effects in fluid film bearings. In Proceedings of the in 6th Leeds-Lyon Sympos, Lyon, France, 18-21 September 1979; pp. 3-23.

40. Johnson, K.L. Contact mechanics, Cambridge University Press. Cambridge 1985, 108, 659.

41. Johnson, K.L. The strength of surfaces in rolling contact. Proc. IMechE Part C Mech. Eng. Sci. 1989, 203, 151-163. [CrossRef]

42. Johnson, K.L. One Hundred Years of Hertz Contact. Proc. Inst. Mech. Eng. 1982, 196, 363-378. [CrossRef]

43. Johnson, K.L.; Kendall, K.; Roberts, A.D. Surface energy and the contact of elastic solids. Proc. R. Soc. Lond. Ser. A Math. Phys. Sci. 1971, 324, 301-313.

44. Ioannides, E.; Pareti, G. Fatigue life predictions in line contacts with and without edge stresses. Proc. Int. Conf. 1986, 1, 211-218.

45. Kannel, J.W.; Tevaarwerk, J.L. Subsurface stress evaluations under rolling/sliding contacts. J. Tribol. 1984, 106, 96-103. [CrossRef]

46. Czyżewski, T. Influence of a tension stress field introduced in the elastohydrodynamic contact zone on rolling contact fatigue. Wear 1975, 34, 201-214. [CrossRef]

47. Johns-Rahnejat, P.M.; Gohar, R. Point contact elastohydrodynamic pressure distribution and sub-surface stress field. In Proceedings of the Tri-annual Conf. on Multi-body Dynamics: Monitoring and Simulation Techniques, Bradford, UK, 15 March 1997.

48. Dowson, D.; Hamrock, B.J. Numerical Evaluation of the Surface Deformation of Elastic Solids Subjected to a Hertzian Contact Stress. ASLE Trans. 1976, 19, 279-286. [CrossRef]

49. Cooper, J.R.; Dowson, D.; Fisher, J.; Isaac, G.H.; Wroblewski, B.M. Observations of residual sub-surface shear strain in the ultrahigh molecular weight polyethylene acetabular cups of hip prostheses. J. Mater. Sci. Mater. Electron. 1994, 5, 52-57. [CrossRef]

50. De Boer, G.N.; Hewson, R.W.; Bryant, M.; Dowson, D. An investigation into the contact between soft elastic and poroelastic bodies rotating under load. Tribol. Mater. Surf. Interfaces 2017, 11, 193-201. [CrossRef]

51. Teodorescu, M.; Rahnejat, H.; Gohar, R.; Dowson, D. Harmonic decomposition analysis of contact mechanics of bonded layered elastic solids. Appl. Math. Model. 2009, 33, 467-485. [CrossRef]

52. Dowson, D.; Higginson, G.R. A Theory of Involute Gear Lubrication; Elsevier: London, UK, 1964; pp. 8-15.

53. Mohammadpour, M.; Theodossiades, S.; Rahnejat, H.; Dowson, D. Non-Newtonian mixed thermo-elastohydrodynamics of hypoid gear pairs. Proc. Inst. Mech. Eng. Part J J. Eng. Tribol. 2017, 232, 1105-1125. [CrossRef]

54. Dowson, D.; Taylor, C.; Yang, L. Friction Modelling for Internal Combustion Engines. Interface Dyn. Proc. 14th Leeds-Lyon Symp. Tribol. 1996, 31, 301-318.

55. Dowson, D.; Taylor, C. Dynamics and lubrication with particular reference to the internal combustion engine, Multi-body Dynamics: Monitoring and Simulation Techniques, 1997, p. 3. 
56. Dowson, D.; Taylor, C.M.; Zhu, G. A transient elastohydrodynamic lubrication analysis of a cam and follower. J. Phys. D Appl. Phys. 1992, 25, A313-A320. [CrossRef]

57. Dowson, D.; Harrison, P.; Taylor, C.M.; Zhu, G. Experimental observation of lubricant film state between a cam and bucket follower using the electrical resistivity technique. Proc. Jpn. Int. Trib. Conf. 1990, 119-124.

58. Hamilton, G. The hydrodynamics of a cam follower. Tribol. Int. 1980, 13, 113-119. [CrossRef]

59. Brown, S.R.; Hamilton, G.M.; Moore, S.L.; Brown, G.M.H.S.R. Hydrodynamic pressure under a piston ring. Nature 1975, 253, 341-342. [CrossRef]

60. Kannel, J.W. Measurements of Pressures in Rolling Contact. IMechE Conf. Proc. 1965, 180, 135-146.

61. Kannel, J.W. Comparison Between Predicted and Measured Axial Pressure Distribution Between Cylinders. J. Lubr. Technol. 1974, 96, 508-514. [CrossRef]

62. Safa, M.M.A.; Gohar, R. Pressure Distribution Under a Ball Impacting a Thin Lubricant Layer. J. Tribol. 1986, 108, 372-376. [CrossRef]

63. Gohar, R.; Safa, M.M.A. Measurement of contact pressure under elastohydrodynamic lubrication conditions. In Tribology and Dynamics of Engine and Powertrain; Woodhead Publishing: Cambridge, UK, 2010; pp. 222-245.

64. Johns-Rahnejat, P.M.; Gohar, R. Measuring contact pressure distributions under elastohydrodynamic point contacts. Tribotest 1994, 1, 33-53. [CrossRef]

65. Mohammadpour, M.; Johns-Rahnejat, P.M.; Rahnejat, H.; Gohar, R. Boundary Conditions for Elastohydrodynamics of Circular Point Contacts. Tribol. Lett. 2013, 53, 107-118. [CrossRef]

66. Dowson, D.; Ruddy, B.L.; Economou, P.N. The elastohydrodynamic lubrication of piston rings. Proc. R. Soc. Lond. Ser. A Math. Phys. Sci. 1983, 386, 409-430.

67. Priest, M.; Dowson, D.; Taylor, C.M. Theoretical modelling of cavitation in piston ring lubrication. Proc. Inst. Mech. Eng. Part C J. Mech. Eng. Sci. 2000, 214, 435-447. [CrossRef]

68. Rahmani, R.; Rahnejat, H.; Fitzsimons, B.; Dowson, D. The effect of cylinder liner operating temperature on frictional loss and engine emissions in piston ring conjunction. Appl. Energy 2017, 191, 568-581. [CrossRef]

69. Howell-Smith, S.; Rahnejat, H.; King, P.D.; Dowson, D. Reducing in-cylinder parasitic losses through surface modification and coating. Proc. Inst. Mech. Eng. Part D J. Automob. Eng. 2014, 228, 391-402. [CrossRef]

70. Rahnejat, H.; Balakrishnan, S.; King, P.D.; Howell-Smith, S. In-Cylinder Friction Reduction Using a Surface Finish Optimization Technique. Proc. Inst. Mech. Eng. Part D J. Automob. Eng. 2006, 220, 1309-1318. [CrossRef]

71. Shahmohamadi, H.; Rahmani, R.; Rahnejat, H.; Garner, C.P.; Dowson, D. Big End Bearing Losses with Thermal Cavitation Flow Under Cylinder Deactivation. Tribol. Lett. 2015, 57, 2. [CrossRef]

72. Morris, N.; Mohammadpour, M.; Rahmani, R.; Johns-Rahnejat, P.; Rahnejat, H.; Dowson, D. Effect of cylinder deactivation on tribological performance of piston compression ring and connecting rod bearing. Tribol. Int. 2018, 120, 243-254. [CrossRef]

73. Charnley, J. The Lubrication of Animal Joints in Relation to Surgical Reconstruction by Arthroplasty. Ann. Rheum. Dis. 1960, 19, 10-19. [CrossRef]

74. MacConaill, M.A. The Function of Intra-Articular Fibrocartilages, with Special Reference to the Knee and Inferior Radio-Ulnar Joints. J. Anat. 1932, 66, 210-227.

75. McCutchen, C.W. Physiological Lubrication. Proc. IMechE Conf. 1966, 181, 55-62.

76. Dowson, D. Paper R2: Review of Symposium on Lubrication and Wear in Living and Artificial Human Joints, London, April 1967. Proc. Inst. Mech. Eng. Conf. Proc. 1966, 181, 226-231. [CrossRef]

77. Dowson, D. Tribology: An Inaugural Lecture by D. Dowson; University of Leeds Press: Leeds, UK, 1968.

78. Walker, P.S.; Dowson, D.; Longfield, M.D.; Wright, V. Boosted lubrication in synovial joints by fluid entrapment and enrichment. Ann. Rheum. Dis. 1968, 27, 512-520. [CrossRef]

79. Dowson, D.; Unsworth, A.; Wright, V. Analysis of 'Boosted Lubrication' in Human Joints. J. Mech. Eng. Sci. 1970, 12, 364-369. [CrossRef]

80. Wiles, P. The surgery of the osteo-arthritic hip. BJS 1958, 45, 488-497. [CrossRef]

81. McKee, G.K.; Watson-Farrar, J. Replacement of arthritic hips by the McKee-Farrar prosthesis. J. Bone Jt. Surg. Br. Vol. 1966, 48, 245-259. [CrossRef]

82. Scales, J.T. Paper 13: Arthroplasty of the Hip Using Foreign Materials: A History. Proc. Inst. Mech. Eng. Conf. Proc. 1966, 181, 63-84. [CrossRef]

83. Dowling, J.; Atkinson, J.R.; Dowson, D.; Charnley, J. The characteristics of acetabular cups worn in the human body. J. Bone Jt. Surg. Br. Vol. 1978, 60, 375-382. [CrossRef] 
84. Reynolds, L.A.; Tansey, E.M. Early Development of Total Hip Replacement; The Wellcome Trust Centre for the History of Medicine at UCL: Los Angeles, CA, USA, 2007.

85. Charnley, J. The Long-Term Results of Low-Friction Arthroplasty of the Hip Performed as a Primary Intervention. J. Bone Jt. Surg. Br. Vol. 1972, 54, 61-76. [CrossRef]

86. Charnley, J.; Kamangar, A.; Longfield, M.D. The optimum size of prosthetic heads in relation to the wear of plastic sockets in total replacement of the hip. Med. Boil. Eng. 1969, 7, 31-39. [CrossRef]

87. Dowson, D.; Jin, Z.-M. Micro-Elastohydrodynamic Lubrication of Synovial Joints. Eng. Med. 1986, 15, 63-65. [CrossRef]

88. Dowson, D.; Yao, J.Q. Elastohydrodynamic Lubrication of Soft-Layered Solids at Elliptical Contacts: Part 2: Film Thickness Analysis. Proc. Inst. Mech. Eng. Part J J. Eng. Tribol. 1994, 208, 43-52. [CrossRef]

89. Auger, D.D.; Dowson, D.; Fisher, J.; Jin, Z.-M. Friction and Lubrication in Cushion Form Bearings for Artificial Hip Joints. Proc. Inst. Mech. Eng. Part H J. Eng. Med. 1993, 207, 25-33. [CrossRef]

90. Auger, D.D.; Dowson, D.; Fisher, J. Cushion form bearings for total knee joint replacement. Proc. IMechE Part H J. Eng. Med. 1995, 209, 73-81. [CrossRef] [PubMed]

91. Jin, Z.M.; Dowson, D.; Fisher, J. Analysis of fluid film lubrication in artificial hip joint replacements with surfaces of high elastic modulus. Proc. Inst. Mech. Eng. Part H J. Eng. Med. 1997, 211, 247-256. [CrossRef]

92. Atkinson, J.; Dowson, D.; Isaac, J.; Wroblewski, B. Laboratory wear tests and clinical observations of the penetration of femoral heads into acetabular cups in total replacement hip joints. Wear 1985, 104, 225-244. [CrossRef]

93. Dowson, D. A comparative study of the performance of metallic and ceramic femoral head components in total replacement hip joints. Wear 1995, 190, 171-183. [CrossRef]

94. Lancaster, J.G.; Dowson, D.; Isaac, G.H.; Fisher, J. The wear of ultra-high molecular weight polyethylene sliding on metallic and ceramic counterfaces representative of current femoral surfaces in joint replacement. Proc. Inst. Mech. Eng. Part H J. Eng. Med. 1997, 211, 17-24. [CrossRef] [PubMed]

95. Smith, S.L.; Dowson, D.; Goldsmith, A.A.J. The effect of femoral head diameter upon lubrication and wear of metal-on-metal total hip replacements. Proc. Inst. Mech. Eng. Part H J. Eng. Med. 2001, 215, 161-170. [CrossRef] [PubMed]

96. Goddard, R.; Dowson, D.; Wright, V. A study in vivo of the stiffness of the human knee. Ann. Rheum. Dis. 1970, 29, 689. [CrossRef]

97. Seedhom, B.B.; Longton, E.B.; Wright, V.; Dowson, D. Dimensions of the knee. Radiographic and autopsy study of sizes required by a knee prosthesis. Ann. Rheum. Dis. 1972, 31, 54-58. [CrossRef] [PubMed]

98. Seedhom, B.B.; Dowson, D.; Wright, V. Functions of the menisci, a preliminary study. Ann. Rheum. Dis. 1974, 33, 111. [CrossRef]

99. Such, C.H.; Unsworth, A.; Wright, V.; Dowson, D.; Pavelka, K.; Meier-Ruge, W.; Müller, W.; Fridrich, R. Quantitative study of stiffness in the knee joint. Ann. Rheum. Dis. 1975, 34, 286-291. [CrossRef]

100. Dowson, D.; Gillis, B.J.; Atkinson, J.R. Penetration of metallic femoral components into polymeric tibial components observed in a knee joint simulator. In Polymer Wear and Its Control; ACS: New York, NY, USA, 1985.

101. Dowson, D. New joints for the Millennium: Wear control in total replacement hip joints. Proc. Inst. Mech. Eng. Part H J. Eng. Med. 2001, 215, 335-358. [CrossRef] [PubMed]

102. Dowson, D.; Hardaker, C.; Flett, M.; Isaac, G.H. A hip joint simulator study of the performance of metal-on-metal joints: Part II: Design. J. Arthroplast. 2004, 19, 124-130. [CrossRef]

103. Yan, Y.; Neville, A.; Dowson, D. Tribo-corrosion properties of cobalt-based medical implant alloys in simulated biological environments. Wear 2007, 263, 1105-1111. [CrossRef]

104. Hesketh, J.; Ward, M.; Dowson, D.; Neville, A. The composition of tribofilms produced on metal-on-metal hip bearings. Biomaterials 2014, 35, 2113-2119. [CrossRef] [PubMed]

105. Beadling, A.R.; Bryant, M.; Dowson, D.; Neville, A. Tribocorrosion of hard-on-hard total hip replacements with metal and ceramic counterfaces under standard and adverse loading conditions. Tribol. Int. 2016, 103, 359-367. [CrossRef]

106. Gao, L.; Dowson, D.; Hewson, R.W. A numerical study of non-Newtonian transient elastohydrodynamic lubrication of metal-on-metal hip prostheses. Tribol. Int. 2016, 93, 486-494. [CrossRef] 
107. Gao, L.; Dowson, D.; Hewson, R.W. Predictive wear modeling of the articulating metal-on-metal hip replacements. J. Biomed. Mater. Res. Part B Appl. Biomater. 2015, 105, 497-506. [CrossRef] [PubMed]

108. Urueña, J.M.; McGhee, E.O.; Angelini, T.E.; Dowson, D.; Sawyer, W.G.; Pitenis, A.A. Normal Load Scaling of Friction in Gemini Hydrogels. Biotribology 2018, 13, 30-35. [CrossRef]

(C) 2020 by the authors. Licensee MDPI, Basel, Switzerland. This article is an open access article distributed under the terms and conditions of the Creative Commons Attribution (CC BY) license (http://creativecommons.org/licenses/by/4.0/). 